Politik Indonesia: Indonesian Political Science Review 1 (1) (2016) 30-44

Politik Indonesia

Indonesian Political Science Review

http://journal.unnes.ac.id/nju/index.php/JPI

\title{
Politisasi Media di 2014: Aburizal Bakrie dan Segmen Pemilih Pemula
}

\author{
Ardian Bakhtiar Rivai ${ }^{1 凶}$ \\ ${ }^{1}$ Universitas Ahmad Dahlan, Indonesia
}

\section{Info Artikel}

Sejarah Artikel:

Diterima 7 Juli 2015

Disetujui 15 Desember 2015

Dipublikasi 15 Januari 2016

Keywords:

Media; Young Voters; 2014

Indonesian Election

\begin{abstract}
Abstrak
Paper ini menjelaskan pengaruh televisi pada perilaku politik di Indonesia pada pemilu 2014. Kajian ini menjadi penting dalam mengidentifikasi bahwa televisi di Indonesia merupakan alat pemodal untuk mengkonstruksi perspesi politik masyarakat Indonesia. Sumber-sumber informasi publik pada televisi di Indonesia bukan merupakan sumber yang benar-benar objektif, namun demikian didominasi oleh mendia yang memiliki kepentingan atas informasi yang akan disampaikan. Artikel ini fokus pada pemahaman pemilih pemula yang memiliki kontribusi tinggi dalam suara pemilu di Indonesia. Kajian pustaka dan analisis digunakan untuk memetakan dominasi media dan mendukung argumentasi bahwa media memiliki pengaruh yang tinggi khususnya televisi. Melalui penjelasan dalam artikel ini, dapat disimpulkan bahwa pemilu 2014 di Indonesia bukan sepenuhnya kompetisi antar kandidat, melainkan kompetisi pemilik media.
\end{abstract}

\begin{abstract}
This paper investigates that influence of television for political behavior in Indonesian election on 2014. There is important to identify that televisions in Indonesia is a tool of capital to construct political perception of Indonesian citizens. Public resources information as television in Indonesia has not really objective, in addition there are the domination of media owner interesting for news information which is published. This paper focuses on understanding on young citizen segmentation whose have the high contribution for Indonesian election voters. Literature review and analytical are applied to the media domination model for support argumentation of highly influences of television in Indonesia. Based on explanation in this paper, we can understand that Indonesian election 2014 is not only about competition of candidate, it is clear that media owner competition.
\end{abstract}

(C) 2016 Universitas Negeri Semarang

Alamat korespondensi: ISSN $2477-8060$

Jl. Pramuka No.42, Umbulharjo, Kota Yogyakarta, Daerah Istimewa Yogyakarta 55161, Indonesia

Email: ardian.rivai@ppkn.uad.ac.id 


\section{Pendahuluan}

Studi ini bermaksud untuk menjelaskan pengaruh dominasi televisi yang dikuasai oleh elit partai politik terhadap persepsi politik (pemilih pemula). Tujuannya, menunjukkkan bahwa televisi sesungguhnya adalah alat bagi pemilik modal untuk mempengaruhi perilaku politik pemilih. Kondisi yang demikian, membuka peluang untuk penguasaan televisi oleh aktor-aktor politik tertentu sebagai salah satu strategi kampanye politik pada era modern. Studi ini akan terfokus untuk mengetahui persepsi politik dari kalangan pemilih pemula (remaja).

Segmentasi remaja menjadi penting, karena dari pilihan politik merekalah kelak dapat diprediksi pola perilaku pemilih di masa yang akan datang. Argumen kebaruan yang ditawarkan dalam studi ini yaitu pertama, studi ini melihat pengaruh media massa dalam perspektif kepemilikan media oleh kandidat politik. Aburizal Bakrie sebagai calon presiden dan pemilik TV One memanfaatkan media televisi yang dimilikinya sebagai alat kepentingan politik menuju Pemilu 2014. Yang sudah banyak terjadi adalah, pemilik media dengan kandidat politik merupakan dua pihak yang berbeda, namum dalam studi ini menangkap ada aspek kebaruan dimana pemilik media dan kandidat politik merupakan pihak yang sama.

Kedua, pengaruh dari tayangan iklan politik di media televisi yang membidik kalangan segmen pemilih pemula. Studi yang sudah banyak dilakukan selama ini hanya melihat pengaruh media massa secara umum tanpa ada fokus segmentasi tentang perilaku pemilih. Sehingga, perlu kiranya menambah studi-studi yang sudah ada dengan fokus yang lebih baru. Jumlah pemilih pemula di Indonesia pada tahun 2014 sebanyak 20\% (Sumarno, 2011) dari total jumlah semua pemilih menjadikan studi ini perlu dilakukan. Karena, tingkat labilitas (emosi) usia remaja yang sangat tinggi dan berubah dengan sangat cepat. Oleh karena itu, dapat diasumsikan bahwa remaja, sebagai salah satu golongan dalam "swing voters", sangat mudah dipengaruhi oleh hal-hal baru dari tayangan televisi khususnya dalam hal pilihan politik.

Ketiga, Kalangan remaja juga belum memiliki identitas kepartaian atau aliran politik yang matang seperti apa yang disebut oleh Johnston (2006) sebagai party identification. Sehingga, Studi ini juga berperspektif lain tentang perilaku pemilih di Indonesia. Dari teori yang ada saat ini, dijelaskan bahwa sebagian besar indikator pemilih disebabkan karena faktor kedekatan ideologi pemilih dengan partainya. Untuk tataran usia remaja, tidak bisa diberlakukan, dimana kalangan remaja belum faham politik secara matang seperti layaknya orang dewasa.

Diskursus mengenai pengaruh televisi terhadap perilaku politik telah mengenal adanya dua model utama. Pertama, model dominasi media (McQuail, 1996). Model ini 
meyakini bahwa media massa berkedudukan di bawah institusi sosial lainya, sehingga kadar independensinya terbatas. Yang jelas, model ini menjelaskan besarnya dominasi pengaruh media massa terhadap pembentukan opini publik dan perilaku politik. Berbagai organisasi media cenderung dimiliki dan dikendalikan oleh segelintir orang kuat (McQuail, 1996). Kekuasaan pemilik modal (kapitalis) dapat mengkontrol media untuk menunjang kepentingan-kepentingan dalam mempengaruhi perilaku politik masyarakat.

Kedua, model pluralis (Gurevith, 1986). Model ini berkeyakinan bahwa masyarakat sebagai suatu arena persaingan kelompok dan kepentingan. Disasumsikan tidak ada satu pun kelompok yang dapat memiliki dominasi atas perilaku politik masyarakat. Konsep pluralis ini sangat bertentangan dengan konsep dominasi seperti tersebut di atas. Konsep yang berwatak pluralis ini menjelaskan keanekaragaman dan prediksi adalah unsur yang utama pada setiap aspek media massa. Akar pandangannya, masyarakat terbuka terhadap segala perubahan dan kontrol demokratis, serta tidak didominasi oleh golongan elit atau kelompok tertentu. Konsep pluralis tersebut, menggiring kita kepada pendekatan normatif tentang media massa untuk mengartikan masyarakat.

Ahmad (2011) menjelaskan bahwa, media massa merupakan salah satu pilar demokrasi yang bebas kepentingan. Atas dasar itulah media massa dikategorikan sebagai ruang publik yang objektif, netral, dan tidak berpihak. Lebih lanjut disampaikan juga, bahwa dunia jurnalisme merupakan dunia yang tidak mungkin disusupi kepentingan politik baik oleh internal organisasi, maupun dari lingkungan luar. Konsep normatif ini didasarkan atas adanya kewajiban media massa sebagai penyedia informasi publik dan kepentingan masyarakat secara keseluruhan.

Fakta yang terjadi di Indonesia saat ini justru kontradiktif bila dikaitkan dengan model pluralis tersebut. Kenyataan ini terlihat dari keterlibatan beberapa pemilik media televisi nasional, yang juga menjadi pimpinan pada salah satu partai politik yang saya sebut sebagai "Raja di Dua Kerajaan". Selain memimpin partai juga memiliki media massa untuk menunjang kepentingan partai yang dipimpinya. Misalnya, Aburizal Bakrie, raja dari TV One dan ANTV yang juga menjabat sebagai ketua umum Partai Golongan Karya (Golkar). Surya Paloh, pendiri Partai Nasdem raja dari Metro TV. Dahlan Iskan, raja 3 stasiun televisi lokal (JTV, Batam TV, dan Riau TV) yang juga menjabat sebagai Menteri BUMN. Dan Hary Tanoesudibjo, raja dari 3 stasiun televisi nasional (MNC TV, RCTI, dan Global TV) yang juga menjabat sebagai ketua dewan pakar Partai Hanura.

Adanya "kerajaan-kerajaan" media massa yang dikuasai oleh pimpinan partai politik tersebut juga mengusik eksistensi 
teori normatif tentang media (normative theories of media) oleh Severin dan Tankard, 2005 (dalam Waluyo dan Drajat, 2008). Dalam teori tersebut diasumsikan bahwa media massa merupakan sumber yang menyediakan kebutuhan informasi bagi masyarakat di era demokrasi sesuai dengan prinsip-prinsip independensi pers. Independen pers inilah yang kemudian menjadi jalur bagi fungsi pers yang tidak dapat dikontrol oleh kepentingan tertentu dalam menyampaikan pemberitaan kepada masyarakat. Oleh karena itulah para penganut teori ini membayangkan bahwa media massa adalah institusi netral yang memegang fungsi penting bagi keterbukaan informasi secara esensial.

Pimpinan partai politik yang juga berkedudukan sebagai "Raja" pada sebuah media massa menimbulkan masalah demokrasi bagi para penganut teori-teori normatif tentang media massa. Hal ini disebabkan oleh anggapan mereka bahwa adanya rajaraja seperti Aburizal Bakrie, Surya Paloh, Hary Tanoesudibjo, dan beberapa pejabat publik seperti Dahlan Iskan (Meneg BUMN) yang juga sebagai penguasa media di Jawa Timur, akan memunculkan masalah baru bagi proses demokrasi di Indonesia. Sebagaimana yang telah disampaikan oleh Ahmad (2011), kepemilikan media massa oleh pimpinan partai politik atau pejabat publik akan menimbulkan dua masalah besar.
Pertama, adanya penyusupan kepentingan politik oleh "Raja Media" tersebut untuk mendukung dan melancarkan kepentingan partai politik atau jabatan publik yang dimilikinya. Kedua, kalangan penganut teori normatif media massa mempermasalahkan adanya kepentingan publik yang terganggu dari hak-hak publik untuk mengkonsumsi informasi. Dalam dimensi politik, adanya kepemilikian media massa oleh "Raja Media" yang juga elit partai politik atau pejabat publik bukanlah sebuah masalah yang perlu dikhawatirkan.

Bagi penganut teori dominasi, kepemilikan media massa oleh pimpinan partai politik atau pejabat publik merupakan salah satu strategi dalam mempengaruhi perilaku politik masyarakat. Dengan menguasai media massa yang menjadi pusat sumber informasi, secara otomatis juga menguasai pembentukan opini publik.

Dengan pembentukan opini publik sesuai kepentingan yang diinginkan, upaya mempengaruhi perilaku politik masyarakat tersebut dapat dilakukan dengan mudah. Hal ini dipengaruhi oleh fakta bahwa pada hakikatnya komunikasi politik modern membutuhkan adanya media untuk distribusi pesan (kepentingan) dari politisi kepada khalayak umum untuk kemudian dapat dibentuk perilaku politiknya (Mutz, 1998 dalam Semetko, 2007).

Gagasan Firmanzah (2008) tentang "Marketing Politik" dan Urbaningrum (2010) tentang "Revolusi Sunyi" bahkan 
merekomendasikan adanya penggunaan media massa sebagai alat untuk menyampaikan pesan-pesan politik yang mereka sebut sebagai strategi media. Penggunaan media massa untuk "marketing politik" juga diamini oleh Urbaningrum (2010) yang menyebutnya sebagai "revolusi sunyi”. Hal ini disebabkan oleh penyampaian pesan kepada masyarakat harus melihat kondisi masyarakatnya. Substansi dari gagasan tentang marketing politik dan revolusi sunyi pada hakikatnya memasukkan media massa sebagai instrumen pokok terhadap kadar kesuksesan dua strategi komunikasi politik itu.

Dalam kacamata komunikasi politik kontemporer, saya menganggap kepemilikan atau penguasaan media massa merupakan sebuah keharusan. Hal ini dikarenakan pola komunikasi politik saat ini harus dilakukan secara masif. Sebagaimana yang telah disampaikan oleh Rush dan Althof, 1997 (dalam Saeful, 2008) bahwa strategi kampanye politik membutuhkan adanya komunikasi politik yang dinamis. Dengan demikian, penggunaan media massa sebagai alat untuk pendistribusian pesan-pesan politik dari politisi kepada masyarakat umum menjadi sebuah keharusan.

Komunikasi politik tersebut sangat berpengaruh bagi kelancaran proses-proses sosialisasi politik, partisipasi politik, dan rekrutmen politik. Agar fokus Studi ini jelas, saya akan membatasi pelacakan saya ini hanya pada pengaruh tayangan iklan di
TV One terhadap persepsi pemilih pemula. Alasan memilih TV One sebagai batasan masalah, dikarenakan TV One merupakan salah satu media massa yang dikuasai oleh Aburizal Bakrie yang menjadi salah satu sumber rujukan utama informasi untuk masyarakat di Indonesia. Selain itu, Aburizal Bakrie sebagai raja TV One sudah mendeklarasikan dirinya sebagai calon presiden untuk siap bertarung di 2014. Sehingga, sudah tampak dengan jelas modus operandi dari Aburizal Bakrie dan TV One yang dikuasainya untuk mendominasi perilaku pemilih di Indonesia.

Apa yang dilakukan oleh "Sang Raja" Aburizal Bakrie, menurut saya merupakan salah satu bentuk ikhtiar komunikasi politik yang memanfaatkan media massa sebagai strategi kampanye politik kepada masyarakat. Metode komunikasi politik secara laten itu dilakukan secara konsisten dalam kemasan acara-acara di televisi. Selain menggambarkan bentuk lain dari komunikasi politik, strategi Bakrie tersebut juga merupakan cara untuk melakukan apa yang disebut oleh Pamungkas (2011) sebagai "Rekrutmen Politik". Pemilihan media yang sesuai untuk menyampaikan pesan-pesan politik (komunikasi politik) juga harus dapat menjangkau semua kalangan masyarakat. 
Kajian Pustaka

Metodologi

Studi ini dilakukan dengan mensurvei

347 siswa-siswi SMA swasta dan negeri di Kota Yogyakarta. Dari hasil survei tersebut kemudian dirangkum beberapa hasil yang penting kemudian disajikan dalam diagram. Memilih siswa-siswi SMA kelas 12 sebagai sampel penelitian merupakan bagian dari strategi representasi kelompok pemilih pemula di Yogyakarta karena rata-rata siswa kelas 12 SMA adalah usia dalam pemilih yang baru pertama kali melakukan pemilihan umum. Sehingga kelompok usia seperti ini sangatlah mewakili bagaimana kondisi pemilih pemula di Kota Yogyakarta. Di sisi lain, dengan memilih siswa-siswi yang sudah masuk di Kelas 12 juga tidak mengganggu proses belajar mengajar di sekolah, karena saat survei ini dilaksanakan sebagian besar dari mereka sedang masuk masa persiapan ujian nasional, sehingga proses belajar mengajar sudah usai dilaksanakan.

\section{Akar Pemahaman Dominasi Media}

Terdapat dua dasar utama seperti dijelaskan oleh Putnam terkait alasan mengapa dominasi televisi dapat mempengaruhi perilaku politik masyarakat. Pertama, hubungan langsung tayangan televisi terhadap minimnya partisipasi politik masyarakat. Berkurangnya partisipasi tersebut disebabkan oleh fakta umum bahwa ketika kita tengah menonton televisi, kita tidak dapat beranjak dari depan televisi untuk terlibat langsung dalam kegiatan-kegiatan sosial kemasyarakatan.

$$
\text { Televisi mengurangi interaksi }
$$

manusia dengan komunitas sosial, baik itu secara langsung maupun tidak langsung (Putnam, 1995b; dalam Uslaner, 1998). Berdasarkan hal tersebut, dapat disimpulkan bahwa semakin sering seseorang menonton televisi, akan semakin sedikit partisipasinya dalam kegiatan-kegiatan sosial kemasyarakatan di lingkunganya, sehingga bukan tidak mungkin akan menimbulkan apatis terhadap kondisi nyata di lingkungan sekitarnya. Kedua, dampak televisi secara personal. Dampak ini dijelaskan Putnam (dalam Uslaner, 1998) bahwa semakin sering kita menonton televisi, maka semakin kita percaya tayangan televisi adalah kondisi sesungguhnya di dunia nyata.

Putnam menyebutnya dengan istilah television world yang diyakini sebagai the real world bagi para penontonya. Dalam konsep ini, Putnam berpendapat bahwa televisi berpengaruh kuat terhadap persepsi masyarakat tentang kehidupan dunia. Putnam mencontohkan bahwa tayangan drama yang menampilkan kekerasan, berita kriminal, peperangan, merebaknya wabah penyakit, dapat menimbulkan efek langsung terhadap perilaku masyarakat yang menontonnya (Uslaner, 1998). Sebagai contoh di Indonesia, ketika stasiun televisi memberitakan tentang makanan Bakso berformalin, maka seketika itu juga masyarakat takut untuk mengkonsumsinya. 
Televisi sebagai salah satu media massa elektronik merupakan instrumen penting bagi pemberdayaan dan pembentukan perilaku politik masyarakat.

\section{Televisi dalam Perspektif Politisasi Media}

Norris (2000) menjelaskan bahwa televisi sebagai salah satu media massa yang paling populer merupakan alat yang efektif digunakan untuk kepentingan politik tertentu. Transformasi pesan politik dari partai atau kandidat tertentu kepada masyarakat mengharuskan pemanfaatan media massa untuk mendapatkan hasil yang maksimal. Efek yang ditimbulkan dari berita di televisi bisa berupa pembelajaran politik, kepercayaan masyarakat kepada: pemimpin, pemerintah, dan televisi juga memiliki efek untuk mobilisasi politik masyarakat secara masif. Lebih lanjut, dapat dijelaskan dari skema berikut ini.

Gambar 1. Skema Politik Media

(Norris, 2000)
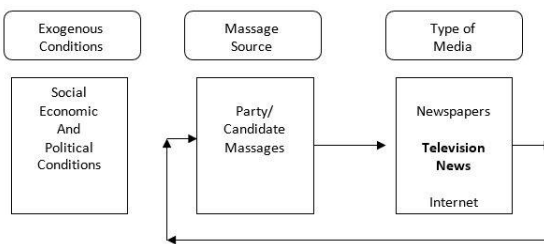

Effects on Civic

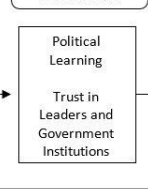

Dari ketiga tipe media seperti yang dijelaskan Norris tersebut, tampaknya untuk saat ini televisi masih menjadi media paling favorit dan yang utama dalam pembentukan perilaku politik pemilih di berbagai belahan dunia, termasuk Indonesia. Seperti dikutip dari data survey yang dilakukan oleh Eurobarometer, 1991 dan
American National Election Studies, 1998 (dalam Norris, 2000) disebutkan bahwa $71 \%$ sumber berita di 15 negara di Eropa berasal dari televisi setiap harinya. Sama halnya dengan Amerika Serikat, sekitar 53\% sumber berita setiap harinya berasal dari televisi. Dua data lembaga survey di eropa dan Amerika tersebut jelas menunjukkan bahwa memang saat ini televisi sangat mendominasi sumber berita untuk masyarakat.

Sejalan dengan penjelasan Norris (2000), McQuail (1996) menyatakan bahwa teori media massa menyajikan dua model pengaruh media. Yaitu, pertama model dominasi media, dimana media massa memiliki pengaruh yang sangat dominan dalam mempengaruhi perilaku pemilih. Kedua, model pluralis media, dimana media massa dianggap sebagai penyambung lidah rakyat kepada penguasa, sehingga logikanya terbalik dengan model dominasi media, yaitu pluralis media justru menganggap media massa yang dipengaruhi oleh aspirasi dan norma yang berlaku di masyarakat demokrasi tersebut.

Model dominasi media merupakan turunan dari aliran Marxisme yang berorientasi kepada kekuatan kepemililikan modal (kapitalis). Sedangkan aliran normatif menyajikan model pluralis. Aliran yang lebih berorientasi kepada norma atau nilai yang berlaku di masyarakat sebagai basis pokok terbitnya sebuah berita di masyarakat. Kedua model turunan tersebut sangat bertentangan satu sama lainya. Model- 
model tersebut saya gunakan dalam membaca kondisi yang terjadi di Tv One.

Dalam diskursus mengenai konsep kekuasaan media massa, maka akan terlihat dua model yang memiliki logika saling bertentangan satu sama lainya. Bila dalam model dominasi, media memiliki khalayak yang dependen dan pasif. Dalam konsep pluralis, media justru dianggap memilii khalayak yang independen dan aktif sebagai instrumen pembentukan suatu berita. Sehingga kedua model ini akan membentuk persepsi secara politik bahwa model dominasi merupakan penjelasan atas konsep kelompok elit dominan yang menggunakan media massa sebagai alat kepentingan politiknya.

Berbeda dengan konsep pluralis yang justru menganggap media massa sebagai arena atau tempat bersaingnya berbagai kelompok politik, sosial, dan budaya dalam pemberitaan atau tayangan di media massa (televisi). Seperti dijelaskan oleh McQuail (1996), bahwa model pluralis dapat saya urai lagi menjadi tiga paradigma pokok untuk menjelaskan konsep pluralis ini sebagai dasar pembacaan media massa di Indonesia.

Pertama, model pluralis dapat menunjukkan adanya cita-cita kebebasan, yang menghendaki tidak adanya kontrol dan pengarahan, kecuali "invisible hand" yang bekerja untuk meningkatkan pemenuhan kebutuhan dan kepentingan seluruh masyarakat. Kedua, model pluralis menguraikan tentang apa yang disebut oleh Gavin (2007) sebagai "tanggung jawab sosial" media dalam sistem demokrasi liberal. Dalam sistem ini, institusi media cenderung dan kadang kala didorong untuk memenuhi kebutuhan masyarakat sesuai dengan batas kewenangan dan kode etik jurnalisme serta berpedoman pada prinsipprinsip profesionalisme media (McQuail, 1996).

Ketiga, model pluralis cenderung menekankan kesukarelaan (voluntarisme) dan independensi khalayak seperti diurai secara singkat dalam tabel di atas. Dengan independensi khalayak tersebut, model ini juga mengakomodasi konsep yang dijelaskan oleh Enzenberger (1970 dalam McQuail, 1996) sebagai media emansipasi. Media emansipasi menjelaskan adanya potensi untuk interaksi, pernyataan diri (self expression) dan realisasi diri (selfrealization), peningkatan kesadaran kelompok atau masyarakat, dan mobilisasi diri (self mobilization). Meminjam definisi McQuail (1996) tentang model kekuasaan media, dapat digambarkan dalam tabel berikut ini.

Gambar 2. Model Kekuasaan Media (McQuaill, 1996)

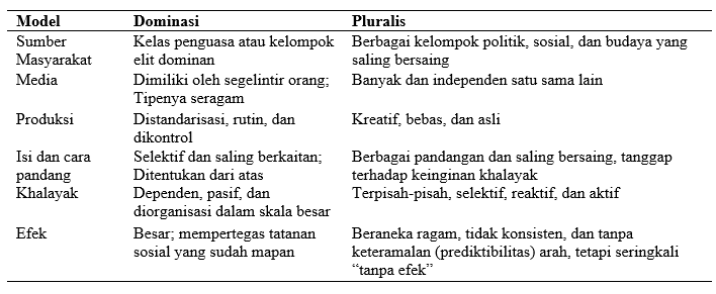


Seperti terlihat dari tabel tersebut, model pluralis menganggap seolah-olah media merupakan cerminan atas cita-cita masyarakat yang bebas dan tidak adanya kontrol serta pengarahan oleh segelintir elit. Model pluralis berasumsi bahwa media massa merupakan abstraksi dari tanggung jawab sosial dalam sistem demokrasi liberal (McQuail, 1996). Namun, model pluarlis ini tidak tepat digunakan untuk membaca kondisi media massa di Indonesia saat ini. Karena, yang terjadi di Indonesia saat ini justru terbalik dengan logika model pluralis tersebut.

\section{Iklan Politik di Televisi}

Dominasi pengaruh iklan politik di media televisi terhadap persepsi politik, membuka peluang yang sangat besar terhadap penggunaan media televisi sebagai alat politik oleh pemilik modal. Sehingga, tidak mengherankan jika saat ini bermunculan banyak pemilik modal yang juga sekaligus menjadi aktor politik. Argumen kebaruan yang dimunculkan dalam studi ini, membuktikan bahwa media massa saat ini tidak lagi bebas nilai seperti yang banyak disuarakan oleh kalangan penganut pendekatan teori normatif media. Media massa seperti televisi hanyalah alat kelas kapitalis untuk mendukung kepentingan politik pribadi atau kelompoknya.

Pertanyaan mendasar dari argumen yang dimunculkan dalam studi ini adalah mengukur sejauh mana signifikansi pengaruh iklan politik di media massa yang dikuasai oleh kelas kapitalis yang juga kandidat politik. Pertanyaan itu juga merupakan pertanyaan untuk membuktikan bagaimana sebenarnya media televisi dimanfaatkan oleh aktor politik tertentu. Pertanyaan semacam itu muncul akibat dari dinamika politik Indonesia saat ini yang membuka peluang penguasaan persepsi publik oleh pengusaha media massa sebagai kandidat calon presiden atau wakil presiden dan jabatan politik lainya.

Disisi lain, studi-studi tentang topik ini belum ada yang menyentuh tentang segmen pemilih pemula. Sehingga, menjadi menarik untuk masuk ke dalam segmen ini sekaligus mengisi kekosongan ruang tentang kajian persepsi politik pemilih pemula. Aspek dialogis yang kemudian muncul dari pembahasan studi ini adalah, argumen kebaruan dalam studi ini dipandang dari empat perspektif. Pertama, aktor dan pemilik medianya merupakan subjek pihak yang sama. Referensi yang sudah ada, menunjukkan bahwa aktor kandidat politik dan pemilik media umumnya merupakan pihak yang berbeda.

Kedua, argumen yang dibangun dalam studi ini bahwa media massa khususnya televisi merupakan satu-satunya alat yang paling efektif untuk membangun, membentuk, dan mengarahkan persepsi politik pemilih. Mau dibawa kemana persepsi politik pemilih sangat bergantung oleh kendali media massa khususnya 
televisi, dan mau dibawa kemana kendali media massa sangat bergantung oleh pemilik modal. Ketiga, pemilih pemula belum memiliki konsep ideologis yang matang, seperti halnya pemilih yang sudah dewasa. Pemilih pemula juga belum mapan secara mental, sehingga sangat potensial untuk terombang-ambing dalam arus budaya populer seperti hal nya iklan politik.

Ada semacam potensi dan peluang yang terbuka lebar untuk pemilik modal untuk masuk ke dalam arena politik di segmen pemilih pemula. Televisi sebagai media massa menyediakan ruang untuk arena politik tersebut. Sehingga, tidaklah menghernkan apabila iklan politik memberikan pengaruh yang signifikan terhadap konstruksi persepsi pemilih pemula tentang Aburizal Bakrie. Keempat, sudah jelas di era kemajuan teknologi dan informasi publik seperti saat ini kapitalisme perilaku politik menjadi teori yang paling relevan untuk menjelaskan kondisi politik Indonesia saat ini.

Kelas-kelas yang memegang kontrol atas produksi dan distribusi, juga secara otomatis akan memegang kontrol mental dan gagasan di zamanya. Aburizal Bakrie sebagai kaum borjuis sudah memposisikan dirinya sebagai raja di dua kerajaan sekaligus. Kerajaan partai politik dan kerajaan media massa. Arena produksi dan distribusi gagasan sudah dimanfaatkanya untuk mempertegas posisinya sebagai kelas pemilik modal seperti yang dijelaskan oleh
Marx. Dari hasil temuan survei yang dilakukan dalam studi ini, dapat disimpulkan beberapa hal terkait bagaimana argumen tentang dominasi iklan politik di media televisi berpengaruh terhadap persepsi pemilih pemula. Pertama, dominasi televisi terhadap pemilih pemula diawali dengan hasil data yang menunjukkan bahwa memang televisi menjadi sumber informasi yang paling utama bagi pemilih pemula di Yogyakarta. Data menunjukkan sebesar $66 \%$ pemilih pemula menganggap sumber informasi berasal dari televisi. Kedua, gaya hidup pemilih pemula saat ini menunjukkan bahwa menonton televisi bukan lagi sekedar mencari hiburan. Tetapi lebih daripada itu, televisi dianggap sebagai partner dalam menjalanan aktifitas rumah dalam kehidupan sehari-hari. Televisi menjadi teman saat para remaja sendirian di rumah, ketika orang tua mereka sibuk dengan urusan karir masing-masing. Televisi menjadi kiblat tentang pola pikir remaja karena juga sekaligus menjadi ruang diskusi akibat ketidak hadiran orang tua pada saat-saat tertentu. Ketiga, iklan politik Aburizal Bakrie memainkan peran sebagai aktor yang melakukan personalisasi perilaku pemilih tentang kandidat presiden di mata pemilih pemula. Pada konteks ini, sesungguhnya media massa televisi menjadi arena politik merebut opini pemilih pemula di Indonesia saat ini. Keempat, selain memainkan peran sebagai personalisasi Aburizal Bakrie di mata 
pemilih pemula, media televisi juga menggugah dimensi emosional pemilih untuk diarahkan kepada sosok kandidat Aburizal Bakrie. Kelima, studi ini berkesimpulan bahwa tingkat popularitas Aburizal Bakrie secara signifikan dipengaruhi oleh faktor sumber informasi, rutinitas menonton televisi, dan personalisasi yang dilakukan oleh iklan politik Aburizal Bakrie di media televisi. Disaat yang bersamaan, indikator rutinitas menonton televisi, dimensi emosional dan personalisasi Aburizal Bakrie juga memberikan pengaruh yang signifikan terhdap penilaian pemilih pemula tentang performance Aburizal Bakrie.

Keenam, tingkat penerimaan pemilih pemula dipengaruhi oleh dimensi emosional yang ditayangkan dalam iklan politik Aburizal Bakrie. Aspek ini menjadi sangat signifikan untuk membentuk bagaimana persepsi politik pemilih pemula diarahkan. Ketujuh, hasil temuan dan uji statistik yang sudah dilakukan membuktikan bahwa memang pada hakikatnya iklan politik Aburizal Bakrie memberikan pengaruh yang signifikan terhadap perpsepsi politik pemilih pemula. Dengan demikian bisa disimpulkan bahwa memang benar media massa televisi saat ini merupakan alat yang paling efektif dalam mendukung proses politik seorang kandidat untuk mencapai tujuan politik yang diinginkan.
Mengukur Popularitas Aburizal Bakrie di Mata Pemilih Pemula

West (1991) menjelaskan bahwa popularitas kandidat adalah hal yang paling mendasar dan paling utama untuk memenangkan kompetisi politik. Popularitas ini dapat diraih dengan menggunakan berbagai cara, salah satunya adalah dengan memanfaatkan media televisi. Popularitas akan mempengaruhi bagaimana sentimen publik terhadap sebuah penampilan dan kepemimpinan seorang kandidat. Lebih lanjut West (1991) menjelaskan bahwa popularitas kandidat akan menjadi indikator awal untuk mengetahui perilaku pemilih kepada salah satu sosok kandidat.

Berangkat dari teori tersebut, menarik kiranya untuk mengetahui bagaimana popularitas Aburizal Bakrie di mata pemilih pemula di Kota Yogyakarta. Ada sekitar 22\% responden yang mengaku sangat mengenal sosok Aburizal Bakrie. Angka tersebut akan semakin besar apabila diakumulasikan dengan pemilih pemula yang menganggap mengenal sosok Aburizal Bakrie yaitu sebesar 27\%. Angka tersebut merupakan angka yang relatif tinggi untuk mengukur bagaimana popularitas sosok Aburizal Bakrie. Karena, responden yang menilai sangat tidak tahu sebesar 3\% dan responden yang menyatakan tidak tahu sebesar $11 \%$. Untuk responden yang menyatakan biasa saja berjumlah sebesar 37\%. Atas dasar data tersebut, bisa ditarik kesimpulan bahwa memang popularitas 
Aburizal Bakrie merupakan sosok yang relatif populer di mata pemilih pemula.

Total tingkat popularitas Aburizal Bakrie bila diakumulasikan antara yang tahu dengan sangat tahu yaitu $49 \%$, jumlah ini relatif cukup memberikan pengaruh yang signifikan sebagai ukuran awal dalam determinasi pengaruh iklan politik Aburizal Bakrie di televisi. Dalam beberapa diskusi dengan responden, diketahui pula bahwa memang Aburizal Bakrie merupakan sosok yang relatif memiliki popularitas yang cukup tinggi di kalangan pemilih pemula di Kota Yogyakarta. Kondisi ini sekaligus mempertegas apa yang dijelaskan oleh West (1991) sebagai bentuk "media influence". Dalam kerangka pemikiran oleh West (1991) tersebut, dijelaskan bahwa memang media khususnya televisi memberikan pengaruh terhadap bagaimana opini publik.

Grafik 1. Popularitas ARB di Mata Pemilih

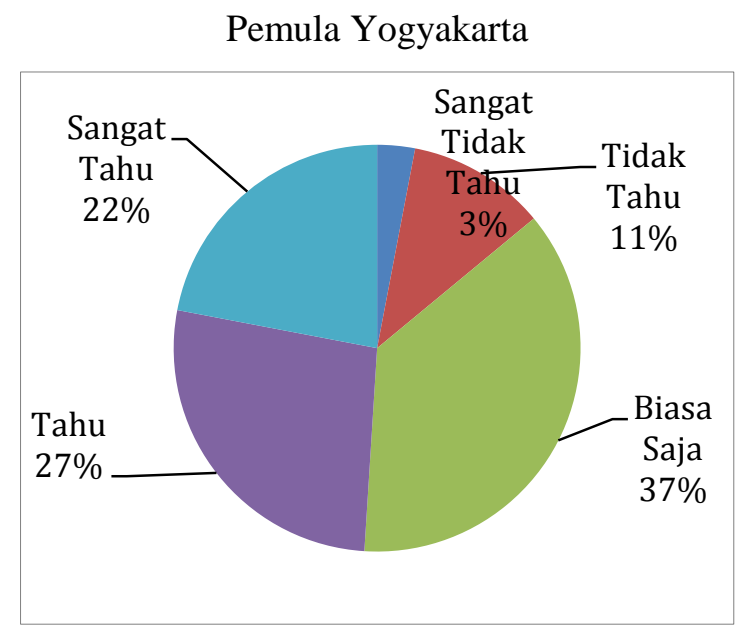

Televisi dianggap sebagai sebuah media yang mampu mempengaruhi atau bahkan membentuk opini publik sesuai dengan yang diinginkan oleh subjek tayangan acara televisi tersebut. Konsep pemikiran tersebut sekaligus dipertegas oleh Robinson (dalam West, 1991) yang menyebutkan bahwa orang yang menonton televisi dianggap sebagai sebuah "the inadvertent audience" karena media televisi pada hakikatnya dapat mengacau perspektif dan cara berfikir penontonya sehingga dengan mudah diarahkan oleh subjek penyusun skenario atau pembuat iklan politik di televisi.

Pada akhirnya, tingkat popularitas Aburizal Bakrie yang relatif tinggi tersebut, mendukung teori yang disampaikan oleh West (1991), bahwasanya televisi merupakan media potensial dan media yang paling berpengaruh dalam membentuk persepsi publik khususnya membentuk perspesi politik seperti yang ditunjukkan oleh iklan politik Aburizal Bakrie. Kondisi yang demikian sebenarnya sudah lama digambarkan oleh berbagai studi di Amerika Serikat yang menunjukkan bahwa televisi menjadi sumber primer pembentukan persepsi publik untuk permaslahatan politik warga negara masing-masing.

Tingginya popularitas Aburizal Bakrie akibat dari gencarnya iklan politik di televisi merupakan bentuk nyata dari teori priming effects seperti yang dipaparkan sangat jelas oleh Lazarsfeld, Berelson, dan Gaudet; 1944 (dalam West, 1991) tentang bagaimana media televisi mampu memberikan pengaruh yang sangat fundamental dan membangkitkan interest penontonya tentang hal-hal yang ditayangkan oleh televisi secara berulangulang. Tayangan iklan politik Aburizal Bakrie yang dilakukan berulang-ulang, tanpa disadari 
juga memberikan pengaruh dalam sikap politik masyarakat khsususnya segmen pemilih pemula dalam menentukan sikap politiknya di masa saat ini dan masa yang akan datang.

\section{Kesimpulan}

Kesimpulan yang bisa dipetik dari penjelasan diatas adalah, bahwa meningkatnya kebutuhan akan komunikasi politik melalui iklan media televisi akan menggugurkan eksistensi dan popularitas partai-partai atau kandidat-kandidat yang hanya mengandalkan ideologi sebagai jualan politiknya. Seperti yang terjadi pada partai-partai atau kandidat yang mengandalkan aspek ideologi, saat ini mulai kehilangan popularitasnya di mata pemilih pemula. Dalam banyak survei yang dilakukan juga menunjukkan bahwa partai-partai berbasis agama semakin tertinggal jauh tingkat popularitasnya di mata pemilih. Seperti, PAN, PKB, PKS, atau bahkan PDS yang sudah gugur dalam medan pertempuran media politik saat ini.

Partai-partai dengan basis agama atau aliran akan gugur dengan sendirinya dan semakin terjun bebas tingkat popularitasnya akibat dari tidak adanya kemampuan sumber daya untuk melakukan komunikasi politik kepada pemilih pemula. Partai atau kandidat yang hanya mengandalkan basis agama seringkali muncul dan mengambil jalan pintas dengan merekrut artis atau selebritis untuk menaikkan tingkat popularitas partai. Pada intinya, bisa disimpulkan bahwa memang kemampuan sosialisasi politik kepada pemilih pemula menjadi hal yang sangat penting untuk memenangkan persaingan politik saat ini yang telah terbawa arus perkembangan teknologi dan informasi.

Dengan semakin meningkatnya kebutuhan akan pembiayaan iklan politik di media televisi, terutama oleh partai politik, calon legislatif, dan calon presiden, juga akan berakibat meningkatnya belanja politik dari partai atau kandidat tersebut. Sehingga, hanya aktor atau partai politik yang ditopang oleh kelas kapitalis yang mampu bertahan dalam proses seleksi alam politik saat ini. Kandidat dan partai politik yang didukung oleh keuangan yang sehat yang mampu bersaing memenangkan persepsi dan perhatian publik. Belanja iklan politik semakin melonjak tatkala musim kampanye dimulai.

Iklan politik, bagaimanapun juga, masih dilihat sebagai pilihan realistis dari aktor politik, terutama kandidat, dalam meraup simpati dan dukungan pemilih. Membanjirnya iklan-iklan politik dalam berbagai bentuk menjelang masa pemilu memperlihatkan tingginya keyakinan para aktor politik, terutama kandidat yang berkompetisi, terhadap kekuatan pengaruh iklan terhadap khalayak dalam menentukan pilihanya. Keberadaan iklan politik di Indonesia saat ini memperlihatkan masih tingginya kepercayaan dan keyakinan para 
kandidat terhadap kekuatan iklan politik. Iklan politik dipercayai memiliki kekuatan yang besar dalam mempengaruhi persepsi pemilih.

\section{Daftar Pustaka}

Ahmad, N. (2011). The Rise of Media Owners in RI Politics. The Jakarta Post 23 November 2011 diakses dari http://www.thejakartapost.com/news/ 2011/11/23/the-rise-mediaowners-ripolitikcs.html tanggal 5 April 2012.

Firmanzah. (2008). Marketing politik: antara pemahaman dan realitas. Yayasan Obor Indonesia.

Gavin, N. (2007). Press and television in British politics: Media, money and mediated democracy. Springer.

Gurevitch, M., \& Levy, M. R. (1986). Information and meaning: Audience explanations of social issues. The main source: Learning from television news, 159-175.

Johnston, R. (2006). Party identification: Unmoved mover or sum of preferences?. Annu. Rev. Polit. Sci., 9, 329-351.

McQuil, D. (1991). Teori Komunikasi Massa: Suatu Pengantar.

Norris, P. (2000). A virtuous circle: Political communications in postindustrial societies. Cambridge University Press.

Pamungkas, S., \& Parlindungan, U. (2011). Partai politik: teori dan praktik di
Indonesia. Institute for Democracy and Welfarism.

Saeful, A. Komunikasi Politik Indonesia Dinamika Islam Politik Pasca Orde.

Semetko, Holli A. (2007). Political Communication. Dalam The Oxford Handbooks of Political Science. Russel J. Dalton, Hans Dieter Klingmann (Editor). Oxford University Press. London.

Sumarno. (2011). Partisipasi Pemilih Muda dalam Pemilukada. Powerpoint Dipresentasikan dalam Sosialisasi Pemilukada untuk BEM dan OKP di DKI Jakarta. Jakarta.

Urbaningrum, A. (2010). Revolusi Sunyi Mengapa Partai Demokrat dan SBY Menang Pemilu 2009?. Penerbit Mizan. Jakarta Selatan.

Uslaner, E. M. (1998). Social capital, television, and the "mean world": Trust, optimism, and civic participation. Political psychology, 19 (3), 441-467.

Waluyo, D., \& Drajat, D. (2008). Mencari Makna Kebebasan Pers dari Komunitas Wartawan: Perspektif Studi Kualitatif Semiotika dan Etnografi. Jurnal Balai Studi dan Pengembangan Wilyah $V$, Kementerian Komunikasi dan Informasi, 2 (5).

West, D. M. (1991). Television and presidential popularity in America. 
Ardian Bakhtiar Rivai/ Politisasi Media di 2014: Aburizal Bakrie dan Segmen Pemilih Pemula

British Journal of Political Science,

21 (02), 199-214. 